\title{
A singular oral appliance to treat obstructive sleep apnea in CPAP non-adherent patients
}

\author{
Denise Fernandes Barbosa ${ }^{1,2}$, Lilian Chrystiane Giannasi ${ }^{3}$, Liege Maria Di Bisceglie Ferreira², \\ Miguel Meira e Cruz ${ }^{4,5}$, Marcelo Corrêa Alves ${ }^{6}$, Fausto Berzin²
}

DOI: https://doi.org/10.1590/2177-6709.25.5.044-050.oar

\begin{abstract}
Introduction: The most prescribed treatment option for Obstructive Sleep Apnea (OSA) is CPAP; however, its adherence is limited. Oral Appliance therapy (OAT) is frequently an option or even an adjuvant, being the mandibular advancement Oral Appliance (OA $)$ the most used prescription. It modifies the upper airway, improving the airway patency. $\mathrm{OA}_{\mathrm{m}}$ construction is based on the occlusal plane to disocclusion. In this study, the DIORS ${ }^{\circledR}$ appliance was used, a singular $\mathrm{OA}_{\mathrm{m}}$, based on Neuro-Occlusal Rehabilitation concepts, that uses Camper's plane as a disocclusion reference, in order to achieve neuromuscular balance and functional stability. Objective: This study primarily aimed to assess the DIORS $S^{\circledR}$ effectiveness in relation to clinical and polysomnographic outcomes. It was also evaluated if the use of DIORS ${ }^{\circledR}$ is as effective as titrated CPAP to treat CPAP non-adherent patients.Methods: Twenty patients were included in this study. Objective and subjective clinical data were assessed at a sleep laboratory using all-night polysomnography, and Epworth Sleepiness Scale (ESS), taken at three moments: Baseline, CPAP titration, and using DIORS ${ }^{\circledR}$. Analysis of respiratory parameters as apnea/hypopnea index (AHI), oxyhemoglobin saturation levels, the arousal index and daytime sleepiness were taken as criteria for a successful OAT. Results: Respiratory and arousal parameters improved in both therapies, while DIORS ${ }^{\circledR}$ promoted a better ESS. Conclusion: Results from the present work support that DIORS ${ }^{\circledR}$ is a viable and effective adjuvant therapy for patients with moderate to severe OSA non-adherent to CPAP.
\end{abstract}

Keywords: Alternative treatment. Oral appliance therapy. Camper plane. Neuro-occlusal rehabilitation.

Introdução: A opção mais indicada para tratamento da apneia obstrutiva do sono (AOS) é o CPAP; contudo, a aderência é limitada. A Terapia com Aparelho Oral (TAO) é, frequentemente, uma opção, ou mesmo um adjuvante. A prescrição mais utilizada é o Aparelho Oral de avanço mandibular $\left(\mathrm{AO}_{\mathrm{m}}\right)$. $\mathrm{O} \mathrm{AO}_{\mathrm{m}}$ modifica a via aérea superior, melhorando a patência do espaço aéreo. A construção do $\mathrm{AO}_{\mathrm{m}}$ se baseia no plano de oclusão para desoclusão. No presente estudo, usamos o DIORS ${ }^{\circledR}$, um $\mathrm{AO}_{\mathrm{m}}$ diferente, baseado nos conceitos da Reabilitação Neuro-Oclusal (RNO), que utiliza o Plano de Camper como referência da desoclusão para alcançar o equilíbrio neuromuscular e estabilidade funcional. Objetivo: O presente estudo teve como objetivo principal abordar a eficácia do DIORS ${ }^{\circledR}$, considerando-se os resultados clínicos e polissonográficos. Adicionalmente, foi avaliado, também, se o uso desse $\mathrm{AO}_{\mathrm{m}}$ é tão eficaz quanto a titulação do CPAP para tratar pacientes com $\mathrm{AOS}$ não aderentes ao CPAP. Métodos: Vinte pacientes foram incluídos neste estudo. Dados clínicos objetivos e subjetivos foram avaliados em um laboratório de sono usando polissonografia de noite inteira e a Escala de Sonolência de Epworth (ESE) observando-se três momentos: inicial, titulação do CPAP e usando o DIORS ${ }^{\circledR}$. Os critérios de sucesso da TAO foram assumidos pela análise dos parâmetros respiratórios como Índice de Apneia e Hipopneia (IAH) e níveis de saturação de oxi-hemoglobina, o índice de despertar e a sonolência diurna. Resultados: Em ambas as terapias, os parâmetros respiratórios e de despertares melhoraram. Adicionalmente, uma melhora na ESE foi alcançada com o DIORS ${ }^{\circledR}$. Conclusão: Os resultados do presente trabalho apoiam que o DIORS $^{\circledR}$ é uma terapia adjuvante viável e bastante eficaz para pacientes com AOS moderada a grave não aderentes ao CPAP.

Palavras-chave: Tratamento alternativo. Terapia com aparelho oral. Plano de Camper. Reabilitação neuro-oclusal.

${ }^{1}$ Private practice (Jundiaí/SP, Brazil).

${ }^{2}$ Universidade de Campinas, Faculdade de Odontologia de Piracicaba (Piracicaba/SP, Brazil).

${ }^{3}$ Universidade Estadual Paulista Júlio Mesquita Filho, Instituto de Ciência e Tecnologia (São José dos Campos/SP, Brazil).

${ }^{4}$ Sleep Unit, Centro Cardiovascular da Universidade de Lisboa, Lisbon School of Medicine, Lisbon, Portugal.

${ }^{5}$ Neuroimune Interface Research Lab, Faculdade São Leopoldo Mandic, Campinas-SP, Brazil.

${ }^{6}$ Universidade de São Paulo, Escola Superior de Agricultura Luiz de Queiroz (Piracicaba/SP, Brazil).
How to cite: Barbosa DF, Giannasi LC, Ferreira LMDB, Meira e Cruz M, Alves MC, Berzin F. A singular oral appliance to treat obstructive sleep apnea in CPAP non-adherent patients. Dental Press J Orthod. 2020 Sept-Oct;25(5):44-50. DOI: https://doi.org/10.1590/2177-6709.25.5.044-050.oar Submitted: July 30, 2019 - Revised and accepted: September 30, 2019

"The author Denise Fernandes Barbosa participates in the invention / development of DIORS ${ }^{\circledast}$ (Dispositivo Intra Oral Restaurador do Sono ${ }^{\circledast}$, Intra Oral Sleep Restoration Device), used in the present research.

Contact address: Denise Fernandes Barbosa Av. Henrique Andrés, 585, Jundiaí/SP - CEP: 13.201-049 E-mail: denise.sono@gmail.com 


\section{INTRODUCTION}

The most prescribed treatment option for $\mathrm{Ob}-$ structive Sleep Apnea (OSA) is Continuous Positive Airway Pressure (CPAP), as this is considered the "gold standard" treatment ${ }^{1}$. However, adherence to CPAP is limited ${ }^{2,3}$ and therefore for non-adherent patients, Oral Appliance Therapy (OAT) is often an option or even an adjuvant treatment. ${ }^{1,4-9}$ The most common type of oral appliance is the mandibular advancement Oral Appliance $\left(\mathrm{OA}_{\mathrm{m}}\right)$. Several studies compare CPAP to $\mathrm{OA}_{\mathrm{m}}$, and show that CPAP is more effective in reducing Apnea/Hypopnea Index (AHI). ${ }^{3,5}$ On the other hand, other studies found a lack of long-term relevant differences between CPAP and $\mathrm{OA}_{\mathrm{m}}$ for mild to moderate OSA, when both treatment modalities are objectively titrated ${ }^{3}$. In addition, excessive sleepiness levels give rise to a primary and clinically important outcome in a sleep apnea patient's follow-up, apparently showing no difference between $\mathrm{OA}_{\mathrm{m}}$ and CPAP treatments. ${ }^{10,11}$ Recent studies have indicated that, despite the advantage of CPAP on AHI reduction, a high compliance to $\mathrm{OA}_{\mathrm{m}}$, compared to $\mathrm{CPAP}^{11}$, leads to similar therapeutic effectiveness.

$\mathrm{OA}_{\mathrm{m}}$ design from the new generation of oral appliances may impact on the therapeutic efficacy and effectiveness, ${ }^{8,11-12}$ with advanced main features, construction techniques, and the ability for individualization. Most $\mathrm{OA}_{\mathrm{m}}$ use the Occlusal Plane (OP) orientation in the construction of dental disocclusion to mandible advancement. Historically, patient's occlusal line has been assessed comparing the inclination to selected craniofacial reference lines. Some authors consider the Camper's Plane (CP) the most suitable plane to orient the OP (Fig 1), based on fixed individual skull structures. Although neither enough long-term studies or authentic data are available advising on a single reliable landmark for the perfect $\mathrm{OP}$, most have suggested CP for artificial orientation of OP..$^{13,14}$

The OP can show differences in the orthogonal planes (sagittal, coronal and transversal), such as a unilateral masticatory function, generating skeletal asymmetries between the reference points of the orthogonal planes. Therefore, in the concepts of Neuro-Occlusal Rehabilitation (NOR),${ }^{15}$ the main reference for a diagnosis is clinical examination of
OP associated with CP to decide which treatment ${ }^{16}$ would bring neuromuscular balance and functional stability. Such diagnosis main tool is Gnathostatic Model (GM), observing the sagittal, coronal and transversal plane, to verify whether or not there is a $\mathrm{CP}$ and $\mathrm{OP}^{15}$ parallelism (Fig 2).

Anatomically, the tongue maintains several relationships with airway space; ${ }^{17,18}$ and so, with the hyoid bone and pharyngeal muscles. ${ }^{19}$ By changing mandible posture and tongue protrusion of an OSA patient, supra-hyoid muscles activity would also change, since it would clearly underline the role of tongue activity in maintaining upper airway patency in upper airway space. ${ }^{20}$

Respecting anatomic and physiologic conditions, and muscle origin and insertion to obtain functional balance, the DIORS ${ }^{\circledR}$ (Dispositivo Intra Oral Restaurador do Sono ${ }^{\circledR}$, Intra Oral Sleep Restoration Device) (Fig 2) was created.

Thus, the present study aimed at evaluating if the use of DIORS ${ }^{\circledR}$, a model of $\mathrm{OA}_{\mathrm{m}}$ using the $\mathrm{CP}$ for orientation to disocclusion, is sufficient to treat OSA patients not adhering to CPAP therapy.

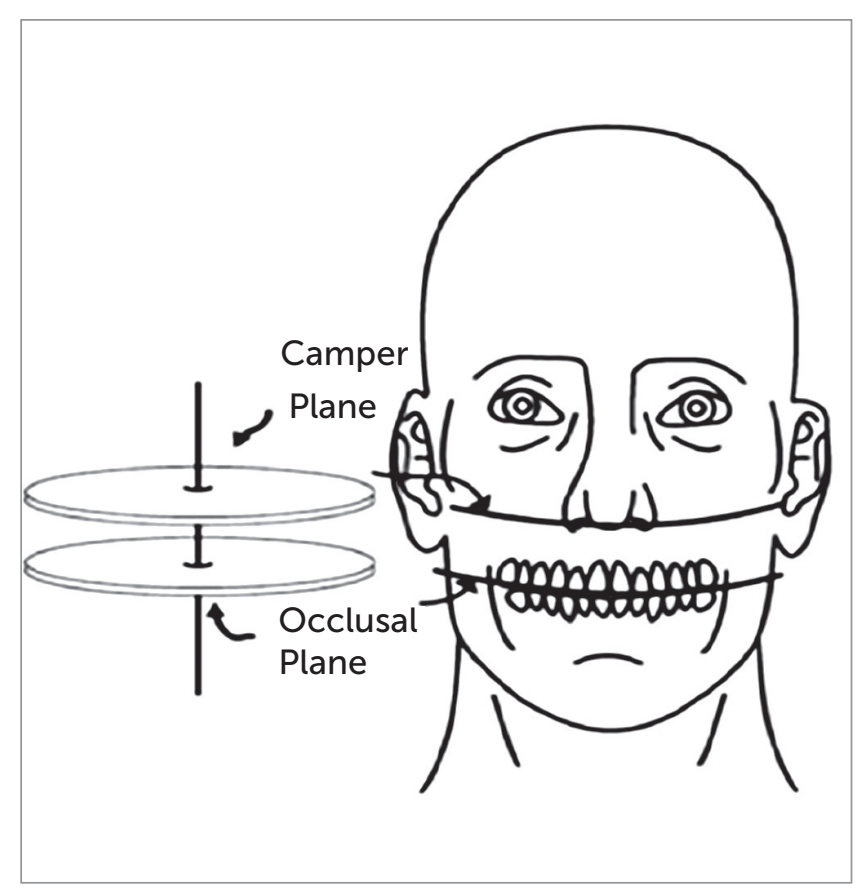

Figure 1 - Frontal view of Camper's plane (ala-tragus) and occlusal plane. 

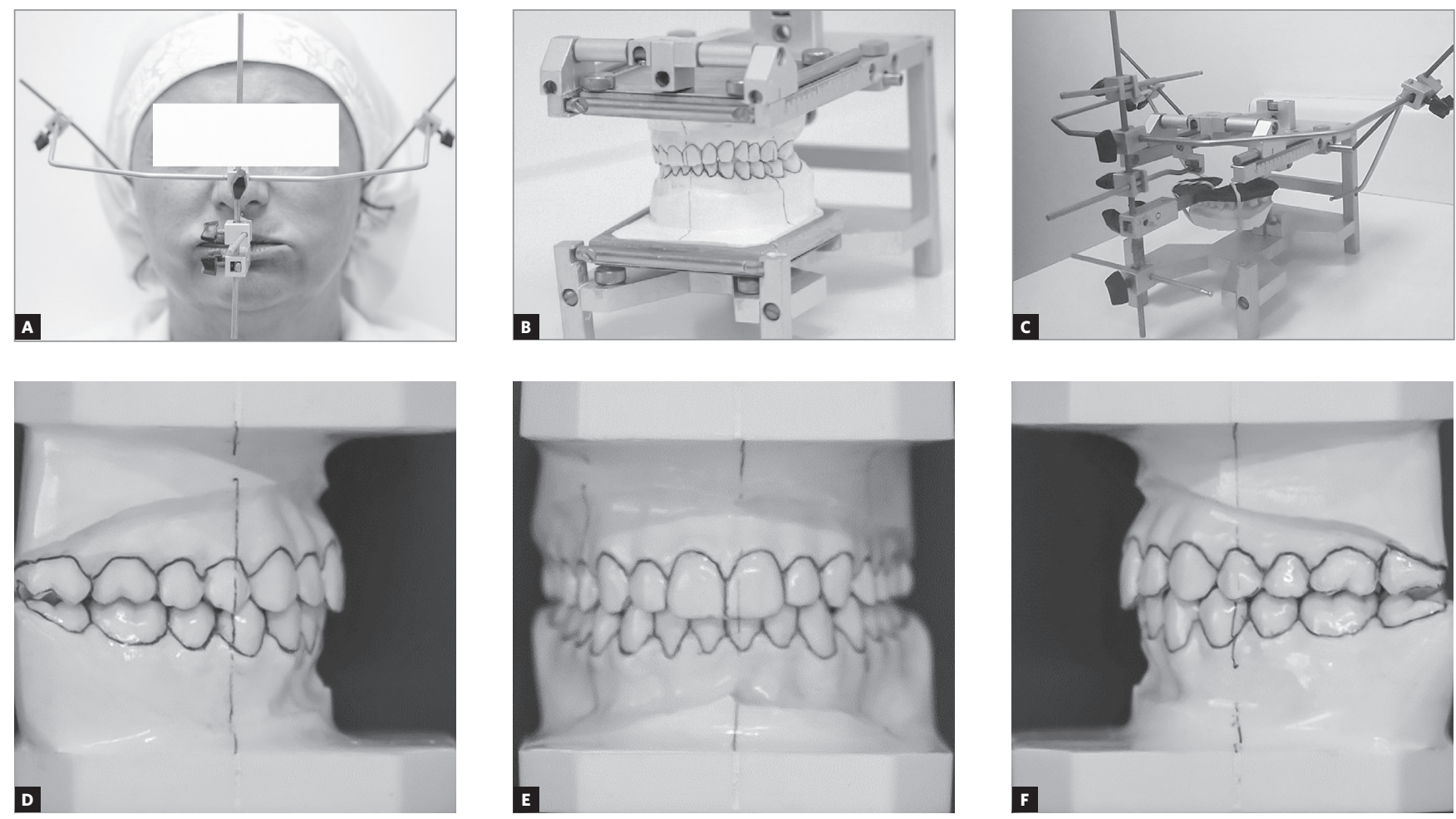

Figure 2 - Modus operandi to make the gnathostatic model: A) gnathostatic facial arch; B) gnathostatic model construction; C) facial arch transferred to the Planas gnathostat to make the gnathostatic model; D) gnathostatic model, right side; E) gnathostatic model, frontal view; F) gnathostatic model, left side.

\section{METHODS}

\section{Study strategy}

To compare the use of DIORS ${ }^{\circledR}$ and CPAP therapy, CPAP non-adherent subjects were selected and the effects of DIORS ${ }^{\circledR}$ were assessed. For this purpose, pre and post OAT subjective data, Epworth Sleepiness Scale (ESS), and polysomnography (PSG) objective data were compared. Three phases of the same patient were assessed: baseline, with CPAP titration (without adherence), and after DIORS ${ }^{\circledR}$ adjustment (with adherence). The criteria for success in therapies were assessed with Arousal Index and respiratory parameters (Apnea/Hypopnea Index [AHI], Oxyhemoglobin Saturation $\left[\mathrm{O}_{2} \mathrm{Sa}\right]$, and daytime sleepiness). At the DIORS ${ }^{\circledR}$ phase, the protocol was of 2-3 month for a change.

\section{Subjects}

The Medical Ethics Committee of the Faculdade de Medicina de Jundiaí (SP, Brasil) (CAAE: 55049616.4.0000.5412 P.N. /1.529.053) approved this study that included patients attending the private clinic of one of the authors.
Anthropometric data of 20 subjects, 11 men and 9 women (Table 1), were consecutively collected. All patients non-adherent to CPAP treatment were indicated to adapt to OAT.

Subjects selected should be adult, man or women, complaining of snoring, sleepiness, choking, with at least 8 teeth per dental arch, with positive diagnosis for OSA by PSG. Data was collected from 7 mild (5-15 ev./h), 8 moderate (16-30 ev./h) and 5 severe (>30 ev./h) OSA subjects. This study excluded patients without all PSG (baseline, CPAP titration and DIORS ${ }^{\circledR}$ advancement), having mandibular advancement of less than $5 \mathrm{~mm}$, a mandibular opening of less than $35 \mathrm{~mm}$, tooth decay, extensive periodontal disease, predominant central sleep apnea, or muscle/joint pain.

\section{Questionnaires}

At a sleep laboratory, the Epworth Sleepiness Scale (ESS) was used to evaluate subjective daytime sleepiness, taken at three moments: baseline, CPAP and DIORS ${ }^{\circledR}$ titration. During the follow-up, partner and patient were interviewed to measure snoring and adherence. 
Table 1 - Mean / SD of baseline anthropometric data of all 20 patients ( $9 \mathrm{~F}$ and $11 \mathrm{M}$ ).

\begin{tabular}{ccc}
\hline Variables & Mean (SD) & $51,91(12.66)$ \\
Age (years) & $28.58(4.76)$ \\
BMl (kg/height $\left.{ }^{2}\right)$ & $39.10(4.39)$ \\
Neck circumference $(\mathrm{cm})$ & $102.05(14.15)$ \\
\hline Waist circumference $(\mathrm{cm})$ & \\
\hline
\end{tabular}

$\mathrm{SD}=$ Standard Deviation; $\mathrm{BMI}=$ Body Mass Index; $\mathrm{F}=$ Male; $\mathrm{M}=$ Male

That moment was also used to assess how safe and resistant is the DIORS ${ }^{\circledR}$ material. The interview included the following questions: "Are you using the DIORS"; "Do you use the DIORS ${ }^{\circledR}$ all night?"; "Do you use the DIORS ${ }^{\circledR}$ every night of the week?"; "Is your partner snoring with the DIORS ${ }^{\circledR}$ ?"; "Are you fully satisfied with the DIORS ${ }^{\circledR}$ ?"; "Has the DIOR ${ }^{\circledR}$ ever broken?”.

\section{Polysomnography}

At the sleep laboratory, each subject was assessed regarding all-night baseline PSG. PSGs with CPAP titration and DIORS ${ }^{\circledR}$ were also assessed (2 to 3 months after $\mathrm{OA}_{\mathrm{m}}$ therapy). For that, sleep specialist physicians used 28-channels Brain Wave II (PSG Neuro Virtual, Barueri/SP, Brazil) following the 2007 AASM Manual for Scoring Sleep ${ }^{21}$. The channels consisted of: Referential AC inputs (8 electroencephalographic [EEG], 2 electrooculogram [EOG], 3 auxiliary); Bipolar AC input (1 electromyogram [EMG], 1 electrocardiogram [ECG], 1 snore, 1 flow, 1 pressure, 1 oximetry, 2 efforts, 1 position, 1 LM and 2 Aux); and 3 DC input. Sleep stages (wake [W]: sleep stage 1 [N1], sleep stage 2 [N2], sleep stage 3 [N3], and sleep stage REM [R]). AHI was defined as the number of episodes of apnea plus episodes of hypopnea per hour of sleep. OSA was defined as $\mathrm{AHI} \geq 5$.

\section{Treatment outcome}

No consensus has been reached on how criteria for success should be defined ${ }^{22}$. Then, three success criteria were established regarding elimination or decreasing of AHI symptoms: 1) Successful (AHI <5/h); 2) Partly successful (at least 50\% reduction in AHI, but AHI $>5 / h$; and 3) Failure (persisting clinical symptoms, and/or less than 50\% reduction in baseline AHI). Symptoms, adhesion, and satisfaction with the use of DIORS ${ }^{\circledR}$ were assessed by means of a questionnaire applied to patients and partners.

\section{Protocol of oral appliance therapy}

First, to build the GM, a detailed anamnesis was performed at the first appointment. Impressions of the dental arches and the face bow were took to construct the GM. To determine the constructive bite, a George Gauge bite fork $^{\mathrm{TM}}$ (Space Maintainers Laboratories, Chatsworth, CA, USA) was used. A specialized dental technician built the custom-made $\mathrm{OA}_{\mathrm{m}}$ with $65-75 \%$ maximum protrusion and a vertical opening of $3-4 \mathrm{~mm}$ between incisor edges. The construction of the DIORS ${ }^{\circledR}$ required two gypsum casts: one for the GM, and one for the working model.

Then, at the second appointment, the DIORS ${ }^{\circledR}$ was placed. From that point, incremental advances of $1 \mathrm{~mm}$ were weekly performed, and the reports of patients regarding their experience with the DIORS ${ }^{\circledR}$ were also recorded. Such reports indicated a decrease in snoring, gasps, sleepiness, and/or based on physiological limitations. The efficacy of the DIORS ${ }^{\circledR}$ was determined by using additional PSG with DIORS ${ }^{\circledR}$ in situ, after at least 3 months.

\section{DIORS $^{\circledR}$ construction, disocclusion, and advancement mechanism ${ }^{20}$}

The construction of this $\mathrm{OA}_{\mathrm{m}}$ is based on the definition of an $\mathrm{OA}_{\mathrm{m}}$ published by the AADSM ${ }^{23}$. Briefly, the DIORS ${ }^{\circledR}$ presented in this study is significantly different because it creates disocclusion and a position that allows a mechanism of advancement positioned on the posterior $2 / 3$ of the tongue, on the lingual surface of the teeth.

Disocclusion is guided by the CP through a device that replicates $\mathrm{CP}$ in the working model. Therefore, the DIORS ${ }^{\circledR}$ performance promotes the protrusion of both the mandible and tongue (Fig 3).

Additionally, this $\mathrm{OA}_{\mathrm{m}}$ is duly patented with the National Institute of Intellectual Property (INPI, patent MU 202012025341-6), registered under numbers 904831639 (DIORS ${ }^{\circledR}$ ) and 906.231.833 


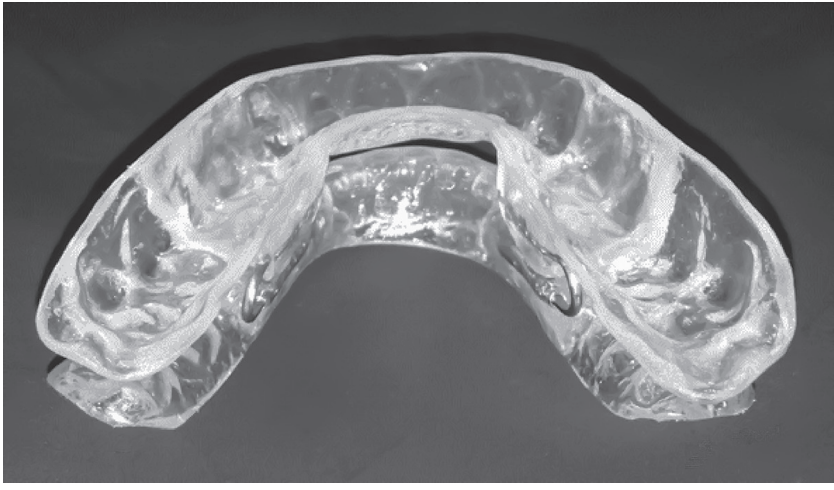

Figure 3 - DIORS ${ }^{\circledR}$ Brazilian $\mathrm{OA}_{\mathrm{m}}$ (Intra Oral Sleep Restoring Device).

(DIORS ${ }^{\circledR}$, Dispositivo Intra Oral Restaurador do Sono ${ }^{\circledR}$, or Intra Oral Sleep Restoring Device).

\section{Statistical analysis}

First, descriptive statistics was used to characterize the sample. Then, an ANOVA generalized linear mixed model was set to compare the three experimental conditions as repeated measures. Based on the Shapiro-Wilk test and asymmetry and kurtosis coefficients, the residual adherence to Gaussian distribution was assessed. The Tukey-Kramer test was applied as post-hoc test.
Based on the results, state-of-the-art parametric techniques were used to describe a modern procedure to approach the issue. To assess the criteria for success and adherence patterns, chi-square was used, with a significance level of $5 \%$ in all tests.

\section{RESULTS}

Table 2 shows the variables studied. Regarding the success criteria for therapies with AHI, CPAP and DIORS ${ }^{\circledR}$ initial mean values were different $(p=0.0001)$ for the respiratory parameters (such as $\mathrm{AHI}, \mathrm{O}_{2} \mathrm{Sa}_{\text {nadir }}$ and $\mathrm{AI}$ ). Regarding daytime sleepiness, no difference was noticed between CPAP and DIORS $^{\circledR}$ at any sleep phase, except for TST-N2 mean $(p=0.001)$, which remained different at all phases, closer to normal in the DIORS ${ }^{\circledR}$. Compared to the CPAP patients, DIORS ${ }^{\circledR}$ patients reported reduced symptoms $(p=0.01)$ of subjective sleepiness.

Besides, Table 3 shows adherence in DIORS ${ }^{\circledR}$ monitoring $(p<0,05)$. From the sample of individuals, three stopped using the DIORS ${ }^{\circledR}$ due to bariatric surgery $(n=2)$ and dental treatment $(n=1)$.

Table 2 - Mean (SD). ANOVA (p-value) and Tukey's test for variable mean in phases (baseline, after CPAP and titration), Average with equal superscript letters indicate no difference between them. Significance level was established as 5\%.

\begin{tabular}{|c|c|c|c|c|}
\hline Variables & Baseline & CPAP & DIORS $^{\odot}$ & p value \\
\hline $\mathrm{AHI} / \mathrm{h}$ & $27.15(27.90)^{A}$ & $3.55(3.20)^{\text {в }}$ & $6.16(6.70)^{\text {в }}$ & 0.0001 \\
\hline Sleep Latency N1 (min) & $34.87(27.94)^{\mathrm{A}}$ & $38.00(21.82)^{\mathrm{A}}$ & $34.99(24.08)^{\mathrm{A}}$ & NS \\
\hline TST (\%) - N1 & $3.32(3.21)^{\mathrm{A}}$ & $3.65(3.30)^{\mathrm{B}}$ & $2.80(0.71)^{A B}$ & NS \\
\hline TST $(\%)$ - N2 & $59.05(9.13)^{A}$ & $51.56(7.71)^{A B}$ & $55.10(5.54)^{B}$ & 0.0015 \\
\hline TST $(\%)-N 3$ & $17.91(6.96)^{A}$ & $23.88(7.86)^{\mathrm{A}}$ & $21.03(5.67)^{A}$ & NS \\
\hline REM (\%) & $19.71(5.02)^{A}$ & $20.91(5.31)^{A}$ & $21.10(2.77)^{A}$ & NS \\
\hline SE $(\%)$ & $76.54(12.84)^{A}$ & $71.62(12.20)^{A}$ & $76.82(10.42)^{A}$ & NS \\
\hline $\mathrm{O}_{2} \mathrm{Sa}_{\text {mean }} / \mathrm{h}(\%)$ & $92.97(1.78)^{\text {В }}$ & $94.65(1.60)^{A}$ & $93.57(1.77)^{B}$ & 0.0005 \\
\hline $\mathrm{O}_{2} \mathrm{Sa}_{\text {nadir }} / \mathrm{h}(\%)$ & $82.68(5.06)^{\text {в }}$ & $88.45(4.51)^{A}$ & $87.45(3.69)^{A}$ & 0.0001 \\
\hline $\mathrm{Al} / \mathrm{h}$ & $23.93(23.08)^{A}$ & $6.56(4.81)^{\mathrm{B}}$ & $6.55(4.89)^{\text {в }}$ & 0.0001 \\
\hline ESS & $9.00(5.77) A B$ & $9.06(5.38)^{A}$ & $7.22(4.05)^{B}$ & 0.0122 \\
\hline $\mathrm{BMI}\left(\mathrm{Kg} / \mathrm{m}^{2}\right)$ & $28.58(4.76)^{A B}$ & $28.69(4.64)^{\text {в }}$ & $29.34(4.30)^{A}$ & 0.044 \\
\hline CPAP titration $\left(\mathrm{cm} / \mathrm{H}_{2} \mathrm{O}\right)$ & - & 7.30 (1.92) & - & - \\
\hline $\mathrm{OA}_{\mathrm{m}}$ advancement (mm) & - & - & $9.84(2.67)$ & - \\
\hline
\end{tabular}

$\mathrm{P}<0.05 . \mathrm{AHI}=$ Apnea/Hypopnea Index; TST= Total Sleep Time; N1= sleep stage 1; N2=sleep stage 2; N3= sleep stage 3; REM= Rapid Eye Movement; SE = Sleep Efficiency; $\mathrm{O}_{2} \mathrm{Sa}=$ Oxyhemoglobin Saturation; $\mathrm{Al}=$ Arousal Index; ESS= Epworth Sleep Scale; OA = Oral Appliance with mandibular advancement; $\mathrm{CPAP}=\mathrm{Con}-$ tinuous Positive Airway Pressure; NS- Non-Significant. A, B and AB= Superscript letters representing the Tukey test with a significantly different form. 
Table 3 - Affirmative descriptive data about follow-up of DIORS ${ }^{\circledR}$ OA usage in 20 patients and partners interview (Chi-square test).

\begin{tabular}{|c|c|c|}
\hline Questions & Yes - percentage (n) & p-value \\
\hline Are you using the DIORS ${ }^{\otimes} ?$ & $85 \%(17)$ & 0.002 \\
\hline Do you use the DIORS ${ }^{\circledR}$ all night? & $85 \%(17)$ & 0.002 \\
\hline Do you use the DIORS ${ }^{\circledR}$ every night of the week? & $88.23 \%(15)$ & 0.002 \\
\hline Is your partner snoring with the DIORS ${ }^{\circledR}$ ? & $58.8 \%(10)$ & 0.467 \\
\hline Are you totally satisfied with the DIORS ${ }^{\oplus}$ ? & $88.23 \%(15)$ & 0.002 \\
\hline Has the DIORS ${ }^{\circledR}$ ever broken? & $5 \%(1)$ & 0.001 \\
\hline
\end{tabular}

$\mathrm{OA}_{\mathrm{m}}=$ Oral Appliance with mandibular advancement.

\section{DISCUSSION}

Although it is almost unknown ${ }^{24}$ to what extent the design of an $\mathrm{OA}_{\mathrm{m}}$ impacts its efficacy, the present study shows that, compared to CPAP tritation, the DIORS $^{\circledR}$ may be a good alternative to CPAP nonadherent patients (Table 2), providing significant objective and subjective improvements.

Despite being considered a gold-standard therapy for moderate to severe OSA, ${ }^{25,26}$ efficiently reducing AHI,$^{24,26,27}$ some authors ${ }^{2}$ criticize the CPAP concept due to its low adherence. Therefore, sleep physicians should monitor treatment adherence, and offer the oral appliance for $\mathrm{OSA}^{27}$ treatment to patients who do not adhere to CPAP therapy. This study demonstrates an alternative solution for that problem.

Many circumstances make AHI a controversial value, since it relies on the duration of events, temporal position of the events (NREM vs REM), or even especial conditions (chronic lung diseases, for instance). For that reason, additional parameters were used to better define severity in the present data sample. Hence, together with AHI and Oxygen Saturation, the results here discussed regarding the arousal index — this is considered an important parameter not only because it is an alternative criterion for scoring hypopneas, but also because it is important in the sum of total sleep duration, which is directly related to either sleepiness and cardiometabolic risk in OSA patients.

Although BMI has significantly increased in the DIORS $^{\circledR}$ therapy, actual parameters demonstrate a relevant improvement of respiratory (AHI and $\mathrm{O}_{2} \mathrm{Sa}$ ) and AI (Table 2) parameters. As the main objective of the therapy, such results show good efficacy, as previously described for mild, moderate and severe OSA, supporting the use of DIORS ${ }^{\circledR}$ based on clinical practice evidence. ${ }^{1-3,5,8-11,17,20,25,27}$ It also reestablished respiratory parameters to normal range $(\mathrm{AHI}<5 / \mathrm{h}$; $p=0.0001$ and $\left.\mathrm{O}_{2} \mathrm{Sa}_{\text {mean }}>93 \% ; p=0.0005\right)$, restored sleep (AI $<10 / \mathrm{h} ; p=0.0001)$, and reduced daytime sleepiness (ESS; $p=0.01)$.

The philosophy of the NOR ${ }^{15,16}$ and gnathological school ${ }^{13,14}$ advocate that the CP is the best reference plane for the occlusal rehabilitation because it promotes functional stability during stomatognathic functions. The DIORS ${ }^{\circledR}$ design respects the same principles, in search for a better OAT adherence, with stability and neuromuscular balance, providing a good prognosis and successful treatment outcomes.

Previous studies ${ }^{28,29}$ report on objective and subjective adherence data, showing that the adherence of $\mathrm{OA}_{\mathrm{m}}$ was about $83 \%$ when objectively evaluated, and $92 \%$ when subjectively assessed. In the present study, the DIORS ${ }^{\circledR}$ had no objective measure to evaluate adherence, justifying the use of a questionnaire to obtain data of adherence and symptoms. In Table 3, due to patient comfort and tolerance, ${ }^{27}$ the monitoring data demonstrate $88.23 \%$ of DIORS $^{\circledR}$ adherence showing a slightly higher percentage than in previous $\mathrm{OA}_{\mathrm{m}}$ studies.

Regarding DIORS ${ }^{\circledR}$ safety, resistance, and durability ${ }^{1.24}$, this research showed its stability and efficacy. This $\mathrm{OA}_{\mathrm{m}}$ was able to maintain airway patency at a therapeutic level of protrusion, being only one fracture noticed in the advancement mechanism, with $95 \%$ of safety and resistance.

Finally, for a better treatment outcome, ${ }^{1,7,24,27,30} \mathrm{a}$ sleep doctor and a dental surgeon should compose the multidisciplinary team.

\section{CONCLUSION}

The present study provides an opportunity to investigate the factors likely to determine how to manufacture the $\mathrm{OA}_{\mathrm{m}}$ and how to assess if its design significantly changes neuromuscular responses, prognosis and treatment outcomes. 


\section{Acknowledgments}

The authors would like to thank Dr. Lia R. A. Bittencourt (UNIFESP), for proofreading the manuscript; Dr. Fernanda R. Almeida (UBC-Canada), for suggesting relevant references, structuring and organizing the manuscript; and Ana Carolina Panhan (FOP-UNICAMP), for the initial statistical analysis.

\section{Authors contribution (ORCID (D))}

Denise F. B. (DFB): 0000-0001-7253-6144

Lilian C. Giannasi (LCG): 0000-0001-6609-2794

Liege M. D. B. F. (LMBF): 0000-0002-8506-6214

Miguel M. e Cruz (MMC): 0000-0001-6076-0878 ${ }^{(0)}$

Marcelo C. Alves (MCA): 0000-0002-3463-2642

Fausto Berzin (FB): 0000-0002-9179-1893

Conception or design of the study: DFB, LCG, MMC, MCA, FB. Data acquisition, analysis or interpretation: DFB, LCG, LMBF, MMC, MCA, FB. Writing the article: DFB, LCG, LMBF, MMC, MCA, FB. Critical revision of the article: DFB, LCG, LMBF, MMC, MCA, FB. Final approval of the article: DFB, LCG, LMBF, MMC, MCA, FB. Obtained funding: DFB. Overall responsibility: DFB, FB.

\section{REFERENCES}

1. Ramar K, Dort LC, Katz SG, Lettieri CJ, Harrod CG, Thomas SM, et al. Clinical practice guideline for the treatment of obstructive sleep apnea and snoring with oral appliance therapy: an update for 2015. J Clin Sleep Med. 2015 Jul 15;11(7):773-827.

2. Rotenberg BW, Murariu D, Pang KP. Trends in CPAP adherence over twenty years of data collection: a flattened curve. J Otolaryngol Head Neck Surg. 2016 Aug; 19:45(1):43.

3. Aarab G, Lobbezoo F, Heymans MW, Hamburger HL, Naeije M. Long-term follow-up of a randomized controlled trial of oral appliance therapy in obstructive sleep apnea. Respiration. 2011 Mar 31;82(2):162-8.

4. Gotsopoulos H, Chen C, Qian J, Cistulli PA. Oral appliance therapy improves symptoms in obstructive sleep apnea: a randomized, controlled trial. Am J Respir Crit Care Med. 2002 Sept 1;166(5):743-8.

5. Phillips $C L$, Grunstein RR, Ali Darendeliler M, Mihailidou AS, Srinivasan VK, Yee BJ, et al. Health outcomes of continuous positive airway pressure versus oral appliance treatment for obstructive sleep apnea: a randomized controlled trial. Am J Respir Crit Care Med. 2013 Apr 15;187(8):879-87.

6. Lim J, Lasserson TJ, Fleetham J. Wright JJ. Oral appliances for obstructive sleep apnea. Cochrane Database Syst Rev. 2006 Jan:(1):1-51.

7. Ngiam J, Balasubramanian R, Darendeliler MA, Cheng AT, Waters K, Sullivan CE. Clinical guidelines for oral appliance therapy in the treatment of snoring and obstructive sleep apnoea. Aust Dent J. 2013 Dec;58(4):408-19.
8. Doff MH, Hoekema A, Wijkstra PJ, van der Hoeven JH, Huddleston Slater JJ, de Bont LG, et al. Oral appliance versus continuous positive airway pressure in obstructive sleep apnea syndrome: a 2-year follow-up. Sleep. 2013 Sep 1;36(9):1289-96

9. Pliska BT, Almeida F. Effectiveness and outcome of oral appliance therapy. Dent Clin North Am. 2012 Apr:56(2):433-44.

10. Li W, Xiao L, Hu J. The comparison of CPAP and OA in treatment of patients with OSA: a systematic review and meta-analysis. Respir Care. 2013 Jul;58(7):1184-95.

11. Sutherland K, Phillips CL, Cistulli PA. Efficacy versus effectiveness in the treatment of obstructive sleep apnea: CPAP and oral appliances. J Dent Sleep Med. 2015 Oct 10;2(4):175-81.

12. Ahrens A, McGrath C, Hägg U. A systematic review of the efficacy of oral appliance design in the management of obstructive sleep apnoea. Eur J Orthod. 2011 Jun;33(3):318-24.

13. Al Quran FA, Hazza'a A, Al Nahass N. The position of the occlusal plane in natural and artificial dentitions as related to other craniofacial planes. J Prosthodont. 2010 Dec;19(8):601-5.

14. Sahoo S, Singh D, Raghav D, Singh G, Sarin A, Kumar P. Systematic assessment of the various controversies, difficulties, and current trends in the reestablishment of lost occlusal planes in edentulous patients. Ann Med Health Sci Res. 2014 May-Jun; 4(3):313-9.

15. Planas, P. Rehabilitacion Neuro-Oclusal (RNO). 2a ed. Barcelona: Masson-Salvat Odontología; 1994.

16. Carvalho FR, Lentini-Oliveira DA, Carvalho GMM, Singer JM, Prado LBF, Prado GF, et al. Intra- and interobserver agreement in the diagnosis of malocclusion in sleep-disordered breathing. Arq Neuropsiquiatr. 2014 Feb; 72(2):114-8

17. Schwab RJ, Pasirstein M, Pierson R, et al. Identification of upper airway anatomic risk factors for obstructive sleep apnea with volumetric magnetic resonance imaging. Am J Respir Crit Care Med. 2003:168:522-30.

18. Kairaitis K. Is the pharynx a muscular hydrostat? Med Hypotheses. 2010;74(3) 590-5.

19. Cori JM, O'Donoghue FJ, Jordan AS. Sleeping tongue: current perspectives of genioglossus control in healthy individuals and patients with obstructive sleep apnea. Nat Sci Sleep. 2018 Jun 15:10:169-79.

20. Barbosa DF, Bana LF, Favaro FH, Berzin F, Cruz, MM. Experimentation for possible oral appliance device. In: American Academy of Sleep Medicine. Case Book of Sleep Medicine. 3rd ed. Darien, IL: American Academy of Sleep Medicine;2019.

21. American Academy of Sleep Medicine. The AASM manual for the scoring of sleep and associated events. rules, terminology and technical specifications. Darien, IL: American Academy of Sleep Medicine, 2007.

22. Ferguson KA, Cartwright R, Rogers R, Schmidt-Nowara W. Oral appliances for the treatment of snoring and obstructive sleep apnea: a review. Sleep. 2006 Feb;29(2):244-62.

23. Scherr SC, Dort LC, Almeida FR, Bennett KM, Blumenstock NT, Demko BG, et al. Definition of an effective oral appliance for the treatment of obstructive sleep apnea and snoring: a report of the American Academy of Dental Sleep Medicine. J Dent Sleep Med. 2014 Apr 10;1(1):1-76.

24. Marklund M. Update on oral appliance therapy for OSA. Curr Sleep Med Rep. 2017 Jul 10:3(3):143-51

25. Holley AB, Lettieri CJ, Shah AA. Efficacy of an adjustable oral appliance and comparison with continuous positive airway pressure for the treatment of obstructive sleep apnea syndrome. Chest. 2011 Dec;140(6):1511-6.

26. Schwartz M, Acosta L, Hung YL, Padilla M, Enciso R. Effects of CPAP and mandibular advancement device treatment in obstructive sleep apnea patients: a systematic review and meta-analysis. Sleep Breath. 2018 Sep;22(3):555-68.

27. Hamoda MM, Kohzuka Y, Almeida FR. Oral appliances for the management of OSA: an updated review of the literature. Chest. 2018 Feb;153(2):544-53.

28. Dieltjens M, Braem MJ, Vroegop AV, Wouters K, Verbraecken JA, De Backer WA et al. Objectively measured vs self-reported compliance during oral appliance therapy for sleep-disordered breathing. Chest. 2013 Nov;144(5):1495-502.

29. Vanderveken OM, Dieltjens M, Wouters K, De Backer WA, Van de Heyning PH, Braem MJ. Objective measurement of compliance during oral appliance therapy for sleep-disordered breathing. Thorax. 2013;68(1):91-6.

30. Spencer J, Patel M, Mehta N, Simmons HC 3rd, Bennett T, Bailey JK, et al. Special consideration regarding the assessment and management of patients being treated with mandibular advancement oral appliance therapy for snoring and obstructive sleep apnea. Cranio. 2013 Jan;31(1):10-13. 